\title{
Is the flora of oxbow lakes different from that of fishponds? A comparison of two types of water reservoirs in the Noteć River valley and Bydgoszcz Canal valley (NW Poland)
}

\author{
Barbara Waldon-Rudzionek \\ Kazimierz Wielki University, Institute of Environmental Biology, Department of Botany, \\ Ossolińskich 12, 85-093 Bydgoszcz, Poland, \\ e-mail address: waldon@ukw.edu.pl
}

Received: 16 January 2017/Accepted: 09 June 2017

\begin{abstract}
The study was conducted in the growing seasons of 2011-2013 and involved 10 oxbow lakes located in the vicinity of Chobielin and 10 fishponds near Ślesin (north-western Poland). The oxbow lakes were characterized by a greater floristic diversity (212 species) compared with the ponds (131 species). Their flora has a more natural character, which is manifested in a higher proportion of native species, including non-synanthropic spontaneophytes $(45.3 \%)$ as well as some legally protected species. In the artificial reservoirs, non-native species represented $12.2 \%$ of the total number of species, in natural reservoirs - only $8.5 \%$. The main differences in the spectrum of life forms were manifested in a higher relative abundance of phanerophytes in the vegetation of the oxbow lakes $(10.8 \%)$, and a higher abundance of hydrophytes along with helophytes $(17.6 \%)$, therophytes $(18.3 \%)$, and geophytes $(16.3 \%)$ in the ponds. The flora of the oxbow lakes was represented by species belonging to 20 phytosociological classes, while the flora of the ponds - 14 classes. Molinio-Arrhenatheretea and Phragmitetea australis accounted for the highest relative species abundance in both types of water bodies. Oxbow lakes are characterized by a much greater proportion of species from Querco-Fagetea, almost exclusively non-synanthropic spontaneophytes. Management practices associated with the maintenance of the ponds translate into a higher proportion of ruderal species, by nearly 6\%. As a result, taxa from Artemisietea vulgaris were more numerous in the ponds. Edificators from Lemnetea minoris and Potametea were also abundant there. The differences in the analysed flora, resulting primarily from different origins of the reservoirs and their surroundings (mainly forests in the case of the oxbow lakes and meadows around the ponds), was confirmed by statistical analysis and synanthropization indices. Despite their different origin and management methods, both types of reservoirs are valuable refuges for native flora and are characterized by high and similar values of floristic diversity indices. While the oxbow lakes are protected from degradation as protected habitats, the existence and condition of vegetation in fishponds are entirely dependent on the economic regime of fish farms.
\end{abstract}

Key words: aquatic ecosystems, vascular flora, anthropogenic changes of vegetation, indices of synanthropization, species diversity, valuation of ecosystems.

\section{Introduction}

Oxbow lakes are old riverbeds, cut off as a result of a river carving out a new course, and they usually have a semicircular shape. These are eutrophic reservoirs, usually with stagnant water. Their supply of water is determined by the river and groundwater level, and a lowering of the water table often results in drying and vegetation encroachment.
Management of river valleys by straightening their meandering riverbeds, construction of reservoirs, drainage of wetlands, and building of levees makes the oxbow lakes threatened and endangered components of the landscape of European river valleys (Kucharski et al., 2013). Therefore, they are under legal protection in accordance with Annex I to the Habitats Directive (Załącznik 1 do Dyrektywy, 1992; Obwieszczenie Ministra Środowiska, 2014). 
Both oxbow lakes and ponds - despite their anthropogenic origin - play an important role in the diversity of the natural environment for many plant species, including endangered and rare species (Matìna \& Berka, 1987; Kubù et al., 1994; Hejný, 1990; Krawczyk, 2005; Szumiec, 1995). These small water bodies also act as ecological traps for contaminants migrating within the landscape and increase water retention (Pieczyńska, 1988).

The role of oxbow lakes, representing different stages of vegetation encroachment and characterized by hugely dynamic vegetation has been emphasized by many authors. In Europe, the Drava oxbow lakes in Hungary (Balázs \& Erdős, 2011) and the Tisa oxbow lakes in Serbia are among the most thoroughly studied lakes in terms of flora and vegetation (Knežević et al., 2009). The vegetation of the Warta oxbow lakes was studied, among others, by Wojtaszek (1989), Ratyńska and Szwed (1999), as well as Kucharski et al. (2013). In the Oder valley, they were analysed by Proćków and Proćków (2008), along the Vistula River - by Klama et al. (2012), and in the vicinity of the Bug River - by Tomaszewicz (1969), as well as Dawidek and Ferencz (2005). The vegetation of fishponds was the subject of research conducted in the Czech Republic (Hejný, 1990) and France (Broyer \& Curtet, 2012; Wezel et al., 2013). The specificity of fishponds in central Poland was presented by Podbielkowski (1968), and in the South Podlasie Lowland - by Falkowski and Nowicka-Falkowska (2001, 2004). In southern Greater Poland (Wielkopolska region), they were studied by Gąbka and Dolata (2010). In Lower Silesia, the vegetation of fishponds was researched by Klupak and Szczęśniak (2010), while in the Sandomierz Valley - by Krawczyk (2005). At present, there are no published data on the flora of oxbow lakes and ponds of the Noteć River valley and the Bydgoszcz Canal, which was the inspiration for the present research.

The main objectives of this work are:

- to present the diversity of flora in oxbow lakes of the middle Noteć River, in the vicinity of Chobielin and in fishponds located in the valley of the Bydgoszcz Canal near Ślesin;

- to compare the flora of oxbow lakes and fishponds;

- to assess the synanthropization degree of the reservoirs;

- to determine the role of the studied reservoirs in the preservation of floristic diversity.

It was assumed that the origin of water bodies and consequently the specifics of habitats, and the varied intensity of human impact on two comparable study objects would be reflected in their flora's composition. Due to their natural origin and low anthropopressure, the old riverbeds should be characterized by more natural flora and larger contribution of protected and threatened plant species.

Due to the decline of wetland ecosystems observed for many years in Poland and in Europe, the results may provide the basis for larger analysis and practical actions aimed at biodiversity protection.

\section{Material and methods}

\subsection{Study area}

The adjacent valleys of the Noteć River and the Bydgoszcz Canal, running through the Torun-Eberswalde ice-marginal valley, provide interesting research subjects. Due to their close proximity and similar effects of certain factors, e.g. climate, they may show some similarities, while on the other hand they differ in geomorphology and history, as well as land-use methods.

Due to a relatively small extent of transformation, certain sections of the middle Noteć River valley are characterized by the presence of numerous natural water bodies - oxbow lakes. Most of them can be found in the vicinity of the village of Chobielin, where the river forms numerous meanders. They are less frequent further west, beyond Nakło, where the Noteć River is regulated.

The fishponds in the valleys of the Noteć River and the Bydgoszcz Canal are artificial reservoirs. Their water regime is regulated according to the needs of fisheries and significantly varies throughout the year. Seven fishpond complexes with a total area of approximately 1300 ha are located in the valley of the middle Noteć River and along the Bydgoszcz Canal. The largest ones are located in Występ, Ostrówek, and Ślesin.

According to Kondracki (2000), the analysed area is located within the microregion of the Bydgoszcz Canal valley belonging to the mesoregion of the Torun Basin and the subprovince of the Southern Baltic Lake District.

Ash-alder riverine Fraxino-Alnetum forest is the predominant type of potential vegetation occurring along the valleys of the Noteć River and the Bydgoszcz Canal (Matuszkiewicz, 2008). Over the past centuries, the study area has undergone significant transformation - both in the Noteć River valley as well as in the so-called "dead valley", which is currently drained by the Bydgoszcz Canal built in 1773-1774; most of the area has been deforested and reclaimed, and thus mainly converted into grasslands. Only the most marshy areas are currently covered with alder Carici elongatae-Alnetum forests, ash-alder FraxinoAlnetum forests, and willow shrubs Salicetum cinereae, as well as small patches of Aceri platanoidis-Tilietum platyphylli slope forests that remain on the edges of the Noteć River valley.

Due to the high degree of vegetation naturalness and high nature conservation values, the area was included in the Natura 2000 network: Dolina Noteci ("Noteć River Valley"; PLH300004) and Dolina Środkowej Noteci 
i Kanału Bydgoskiego ("Middle Noteć River and Bydgoszcz Canal Valley"; PLB300001).

The study area included oxbow lakes situated in the valley of the Noteć River near Chobielin and ponds located in the valley of the Bydgoszcz Canal near Ślesin (Fig. 1). The ponds near Ślesin constitute one of the largest complexes of ponds in the region (183.54 ha). A pond named
Kardynalski (not included in this study) is the largest one in this complex. It has an area of ca. 100 ha and has developed from an ancient lake, while other ponds were dug below the ground level.

In the valley of the middle Notec River and along the Bydgoszcz Canal, fishponds are much more numerous and occupy a larger area than oxbow lakes. The surface area

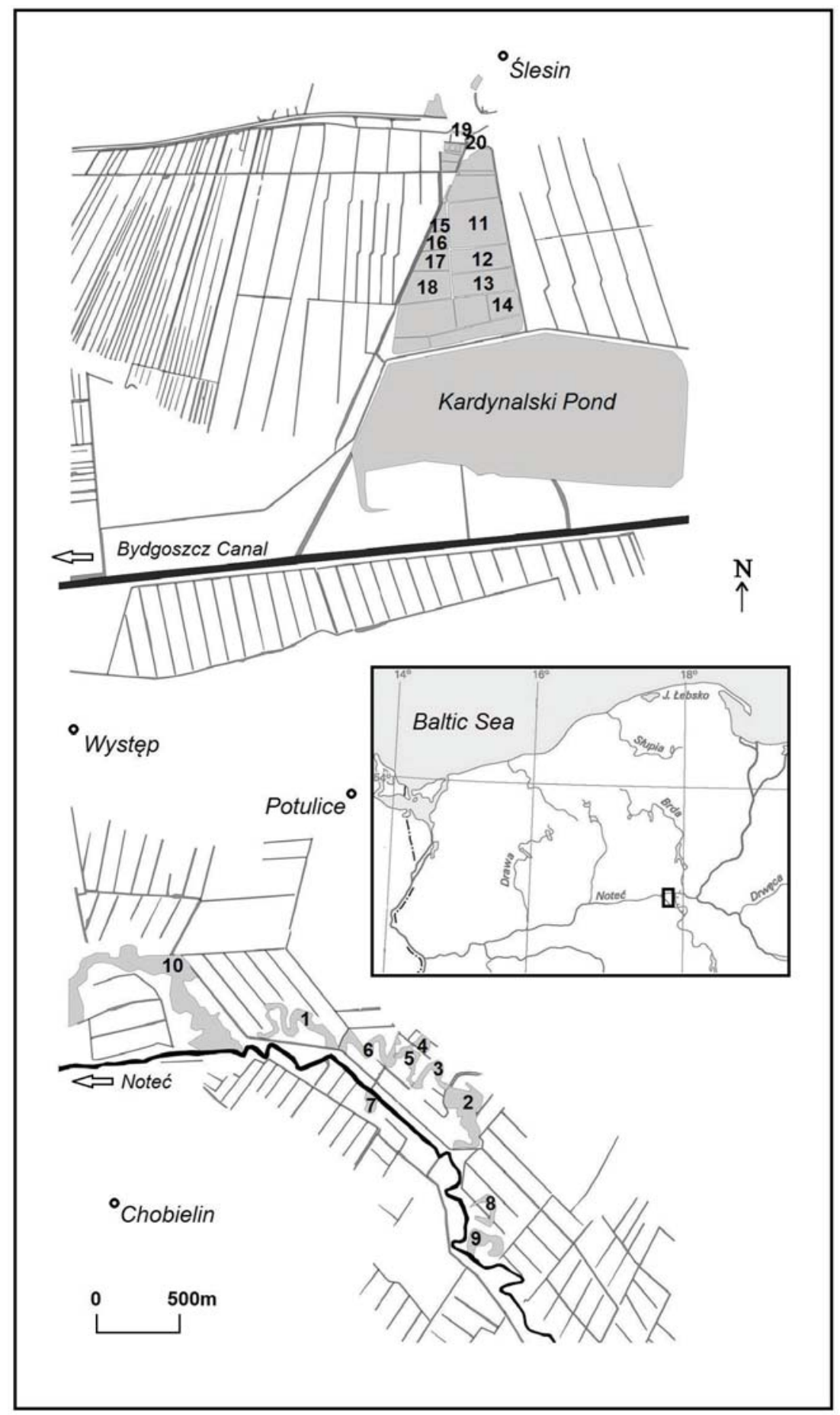

Figure 1. Location of the studied oxbow lakes (1-10) and fishponds (11-20) 
of the examined oxbow lakes ranged from 0.3 to 13.3 ha (on average $2.7 \mathrm{ha}$ ), with the total area of 26.9 ha. The fishponds were generally larger ( 0.1 to 7.0 ha - on average $3.0 \mathrm{ha}$ ) and their total area was 30.1 ha. One oxbow lake was dry, while the others were characterized by a high water level during the study period. The water level was low in one of the fishponds, medium - in two fishponds, and high in the remaining ones (Table 1).

Almost all the studied oxbow lakes are semicircular in shape and are located at the right bank of the Noteć River. Some of them are flooded in spring at higher water levels of the river, while they are often dry in late summer. Fishponds are generally rectangular or triangular with steep shores, and the water level is adjusted in relation to the fish breeding cycle; some of them are periodically completely dry.

\subsection{Fieldwork}

The research was carried out in the growing seasons of 2011-2013. The flora of vascular plants was examined in 10 oxbow lakes located along the Noteć River and 10 ponds supplied by the Bydgoszcz Canal. To obtain comparable results, an equal number of water bodies of each type was taken into account. The study included depressions (usually filled with water) and their immediate, functionally related surroundings. During the study, the water level in the reservoirs was measured and assessed as: high, medium (lowered water level - partially exposed shores), low (water level clearly reduced - partly exposed bottom), and dry.

Each water body was treated as a separate complex of plant communities corresponding to a local aggregation of phytocoenoses according to Solon (1983) and Ratyńska (2003).

In each reservoir, the flora was inventoried according to the Braun-Blanquet (1964) cover-abundance scale. The nomenclature of species followed Mirek et al. (2002) and the affinity of species with phytosociological classes Ratyńska et al. (2010). The life forms of plant species were determined according to Rutkowski (2011). The presence of protected (Rozporządzenie Ministra Środowiska, 2014) and endangered species, both locally (Rutkowski, 1997) and in whole Poland (Kaźmierczakowa et al., 2016), was also taken into account.

The origin of plants and the extent to which they can be considered as domestic (geographical-historical classification) were based on Jackowiak (1990) and Ratyńska et al. (2010).

Based on the geographical and historical classification, indices of anthropogenic changes in the composition of flora were calculated for the studied groups of oxbow lakes and fishponds (Jackowiak, 1990):

- the flora naturalness index $(N)$, describing the contribution of non-synanthropic spontaneophytes $(S p)$ in the whole studied flora $(S+A)$, calculated according to the formula:

$$
N=\frac{S p}{S+A} 100 \%
$$

- the index of flora specific synanthropization $\left(S_{w}\right)$. It determines the percentage of synanthropic spontaneophytes, i.e. apophytes $(A p)$ and anthropophytes $(A)$ in the whole flora:

$$
S_{w}=\frac{A p+A}{S+A} 100 \%
$$

- the specific apophytization index $\left(A p_{w}\right)$ representing the proportion of apophytes $(A p)$ in the studied flora:

$$
A p_{w}=\frac{A p}{S+A} 100 \%
$$

- the total anthropophytization index $\left(A_{n}\right)$ that determines the percentage of anthropophytes $(A)$ in the flora:

$$
A_{n}=\frac{A}{S+A} 100 \%
$$

Principal Component Analysis (PCA) was performed using the MVSP software (Kovach, 2002). Hierarchical classification was carried out using the Unweighted Pair Group Method with Arithmetic Mean (UPGMA). In addition, the index of diversity $\left(H^{\prime}\right)$ according to the Shannon and Weaver (1949) formula and the evenness index were calculated. The base 2 logarithm was used in the calculations.

To determine the significance of differences between the analysed indices, the t-Student test was performed using the Statistica 12 software. A map of the study area was made using Quantum GIS 2.0.

\section{Results}

A total of 248 species of vascular plants were recorded in all the reservoirs and their surroundings, including 213 species occurring in oxbow lakes and 131 in fishponds. The comparison showed that 125 species (i.e. $50.40 \%$ ) are common to both types of water bodies and 155 are exclusive to the distinguished landscape units. Eighty-eight species $(35.48 \%)$ are specific to the flora of oxbow lakes and 67 species $(27.02 \%)$ - to artificial water bodies. The number of species in each fishpond ranged from 28 to 54, with an average of 42 , while the number of species in the oxbow lakes was substantially higher and ranged from 26 to 107 
Table 1. List and characteristics of the studied reservoirs

\begin{tabular}{|c|c|c|c|c|c|c|c|c|}
\hline $\begin{array}{l}\text { No. of } \\
\text { reservoir } \\
\text { (see } \\
\text { Fig. 1) }\end{array}$ & $\begin{array}{l}\text { Type of } \\
\text { reservoir }\end{array}$ & $\begin{array}{l}\text { Coordinates of } \\
\text { the centre }\end{array}$ & $\begin{array}{l}\text { Area } \\
\text { in } \\
\text { ha }\end{array}$ & $\begin{array}{c}\text { Water } \\
\text { level } \\
\text { during the } \\
\text { study }\end{array}$ & $\begin{array}{c}\text { Distance from } \\
\text { the river/canal in } \\
\text { meters (min. - max) }\end{array}$ & $\begin{array}{l}\text { Diversity } \\
\text { index }\end{array}$ & Evenness & $\begin{array}{l}\text { Number } \\
\text { of plant } \\
\text { species }\end{array}$ \\
\hline 1 & Oxbow lake & $\begin{array}{c}\text { N: } 53^{\circ} 6 ’ 32.02^{\prime \prime} \\
\text { E: } 17 \\
{ }^{\circ} 41^{\prime} 29.56^{\prime \prime}\end{array}$ & 2.8 & High & $62-277$ & 4.563 & 0.971 & 26 \\
\hline 2 & Oxbow lake & $\begin{array}{l}\text { N: } 53^{\circ} 6 ’ 22.31^{\prime \prime} \\
\text { E: } 17^{\circ} 42^{\prime} 1.67^{\prime \prime}\end{array}$ & 2.8 & High & $40-376$ & 6.455 & 0.987 & 93 \\
\hline 3 & Oxbow lake & $\begin{array}{c}\mathrm{N}: 53^{\circ} 6{ }^{\prime} 29.52^{\prime \prime} \\
\mathrm{E}: 17 \\
{ }^{\circ} 41^{\prime} 51.63^{\prime \prime}\end{array}$ & 0.9 & High & $175-360$ & 5.346 & 0.979 & 44 \\
\hline 4 & Oxbow lake & $\begin{array}{c}\mathrm{N}: 53^{\circ} 6{ }^{\prime} 34.15^{\prime \prime} \\
\mathrm{E}: 17 \\
{ }^{\circ} 41^{\prime} 48.29^{\prime \prime}\end{array}$ & 0.3 & High & $359-437$ & 5.265 & 0.983 & 41 \\
\hline 5 & Oxbow lake & $\begin{array}{c}\mathrm{N}: 53^{\circ} 6 ’ 30.99 ” \\
\mathrm{E}: 17 \\
{ }^{\circ} 41^{\prime} 45.32^{\prime \prime}\end{array}$ & 0.9 & High & $170-333$ & 5.286 & 0.98 & 42 \\
\hline 6 & Oxbow lake & $\begin{array}{c}\text { N: } 53^{\circ} 6 ’ 31.98^{\prime \prime} \\
\text { E: } 17 \\
{ }^{\circ} 41^{\prime} 29.49^{\prime \prime}\end{array}$ & 2.3 & High & $57-274$ & 6.157 & 0.982 & 77 \\
\hline 7 & Oxbow lake & $\begin{array}{c}\mathrm{N}: 53^{\circ} 6^{\prime} 23.6^{\prime \prime} \\
\mathrm{E}: 17 \\
{ }^{\circ} 41^{\prime} 30.62^{\prime \prime}\end{array}$ & 0.9 & Dried out & $0-98$ & 6.667 & 0.989 & 107 \\
\hline 8 & Oxbow lake & $\begin{array}{l}\text { N: } 53^{\circ} 6^{\prime} 4.8^{\prime \prime} \\
\text { E: } 17^{\circ} 42^{\prime} 9.9^{\prime \prime}\end{array}$ & 1.2 & High & $74-175$ & 5.676 & 0.977 & 56 \\
\hline 9 & Oxbow lake & $\begin{array}{l}\text { N: } 53^{\circ} 5^{\prime} 57.81^{\prime \prime} \\
\text { E: } 1^{\circ} 42^{\prime} 7.05^{\prime \prime}\end{array}$ & 1.5 & High & $0-177$ & 5.508 & 0.981 & 49 \\
\hline 10 & Oxbow lake & $\begin{array}{l}\text { N: } 53^{\circ} 6 ’ 38.93^{\prime \prime} \\
\text { E: } 17^{\circ} 41^{\prime} 7.16^{\prime \prime}\end{array}$ & 13.3 & High & $33-267$ & 6.629 & 0.985 & 106 \\
\hline 11 & Fishpond & $\begin{array}{l}\text { N: } 53^{\circ} 9^{\prime} 3.68^{\prime \prime} \\
\text { E: } 17 \\
{ }^{\circ} 41^{\prime} 59.79 ”\end{array}$ & 7.0 & High & $1640-1910$ & 4.967 & 0.976 & 34 \\
\hline 12 & Fishpond & $\begin{array}{l}\text { N: } 53^{\circ} 8^{\prime} 57.06^{\prime \prime} \\
\text { E: } 1^{\circ} 42^{\prime} 1.34^{\prime \prime}\end{array}$ & 3.5 & Medium & $1520-1640$ & 5.186 & 0.981 & 39 \\
\hline 13 & Fishpond & $\begin{array}{l}\text { N: } 53^{\circ} 8^{\prime} 52.95^{\prime \prime} \\
\text { E: } 17^{\circ} 42^{\prime} 2.04^{\prime \prime}\end{array}$ & 3.0 & Low & $1400-1520$ & 5.367 & 0.977 & 45 \\
\hline 14 & Fishpond & $\begin{array}{l}\text { N: } 53^{\circ} 8^{\prime} 48.7^{\prime \prime} \\
\text { E: } 1^{\circ} 42^{\prime} 8.51^{\prime \prime}\end{array}$ & 0.7 & Medium & $1230-1380$ & 5.537 & 0.986 & 49 \\
\hline 15 & Fishpond & $\begin{array}{c}\text { N: } 53^{\circ} 9 ’ 2.99^{\prime \prime} \\
\text { E: } 17 \\
{ }^{\circ} 41^{\prime} 48.27 ”\end{array}$ & 0.4 & High & $1750-1810$ & 5.197 & 0.983 & 39 \\
\hline 16 & Fishpond & $\begin{array}{l}\text { N: } 53^{\circ} 9^{\prime} 0.12^{\prime \prime} \\
\mathrm{E}: 7^{\circ} 41^{\prime} 47.5^{\prime \prime}\end{array}$ & 1.2 & High & $1650-1750$ & 4.680 & 0.973 & 28 \\
\hline 17 & Fishpond & $\begin{array}{c}\text { N: } 53^{\circ} 8^{\prime} 56.64 " \\
\text { E: } 17 \\
{ }^{\circ} 41^{\prime} 46.97^{\prime \prime}\end{array}$ & 1.9 & High & $1530-1650$ & 5.285 & 0.986 & 41 \\
\hline 18 & Fishpond & $\begin{array}{c}\text { N: } 53^{\circ} 8^{\prime} 52.17^{\prime \prime} \\
\text { E: } 17 \\
{ }^{\circ} 41^{\prime} 44.89^{\prime \prime}\end{array}$ & 4.2 & High & $1360-1540$ & 5.421 & 0.987 & 45 \\
\hline 19 & Fishpond & $\begin{array}{c}\text { N: } 53^{\circ} 9^{\prime} 19.86^{\prime \prime} \\
\text { E: } 17 \\
{ }^{\circ} 41^{\prime} 55.98^{\prime \prime}\end{array}$ & 0.1 & High & $2280-2320$ & 5.642 & 0.980 & 54 \\
\hline 20 & Fishpond & $\begin{array}{l}\text { N: } 53^{\circ} 9^{\prime} 18.76^{\prime \prime} \\
\text { E: } 17 \\
{ }^{\circ} 41^{\prime} 57.05^{\prime \prime}\end{array}$ & 0.1 & High & $2210-2270$ & 5.382 & 0.986 & 44 \\
\hline
\end{tabular}


(in the dry lake), i.e. 64 on average (Table 1). The mean floristic diversity index of all the studied water bodies was 5.51 , and it was higher in the oxbow lakes (5.76) than in the fishponds (5.27). Average values of the evenness index for each type of reservoir were 0.98 . The differences between the diversity and evenness indices for oxbow lakes and fishponds were not statistically significant $(\mathrm{p}=0.06$; $\mathrm{p}=0.97)$, while a statistically significant difference was found for the floristic abundance $(\mathrm{p}=0.04)$.

In total, 8 protected and endangered (both locally and in the whole country) species were identified (Table 2).

Protected taxa found exclusively in the oxbow lakes or their adjacent surroundings include: Angelica archangelica subsp. litoralis, Lathyrus palustris and Menyanthes trifoliata. There were 5 endangered species in the artificial reservoirs: Asperugo procumbens, Batrachium aquatile, Hippuris vulgaris, Senecio congestus and Sonchus palustris. Moreover, locally rare species found in the studied reservoirs included: Lemna gibba, Myosotis sparsiflora, Schoenoplectus tabernaemontani, Stratiotes aloides and Thalictrum flavum.

The following species were very frequent in both reservoir types: Carex acutiformis, Phalaris arundinacea, Symphytum officinale and Urtica dioica. Species with the highest frequencies in the oxbow lakes were: Alnus glutinosa and Iris pseudacorus (absent in fishponds), Calystegia sepium, Carduus crispus, Lemna minor, Lotus uliginosus, Lysimachia vulgaris, Phragmites australis, Poa palustris, Polygonum amphibium f. terrestre, Rorippa palustris, Salix cinerea and Solanum dulcamara. The following species were most numerous in the fishponds: Anthriscus sylvestris, Arrhenatherum elatius, Cirsium oleraceum, Elymus repens, Epilobium hirsutum, Galium aparine, Glyceria maxima, Myosoton aquaticum, Potamogeton pectinatus, Rorippa amphibia and Typha latifolia.

Among the life forms, hemicryptophytes dominated their number was slightly higher in the flora of the oxbow lakes $-41.2 \%$ (Fig. 2). Other groups were therophytes, hydrophytes along with helophytes, and geophytes, which were more numerous in the fishponds. The percentage of megaphanerophytes was much higher in the natural water bodies $(6.6 \%)$ compared to the anthropogenic ones $(1.5 \%)$.

The total flora of all the surveyed reservoirs showed a high degree of naturalness as evidenced by a significant proportion of native species, which was higher in the flora of the oxbow lakes $-91.5 \%$ compared to the artificial water bodies $-87.8 \%$ (Fig. 3). In addition, non-synanthropic spontaneophytes were nearly $5 \%$ more abundant in the natural reservoirs; the flora naturalness index was also higher (Table 3). The fishponds were characterized by a higher contribution of alien taxa $(12.2 \%)$, of which archaeophytes accounted for the largest number (7.6\%). In addition, the synanthropization and specific anthropophytization indices had higher values in the fishponds (Table 3). Among kenophytes present in both natural and artificial water bodies, the following species were recorded: Acorus calamus, Conyza canadensis and Rumex thyrsiflorus. Oxbow lakes hosted additionally neophytes: Bidens frondosa, Elodea canadensis and Padus serotina.

Table 2. List of protected and endangered plant species in oxbow lakes of the Noteć River valley and fishponds in the Bydgoszcz Canal valley. Explanations: PCL - species included on the Red List of plants in Poland (Kaźmierczakowa et al., 2016); R. K-P - endangered species in the Kuyavian-Pomeranian region (Rutkowski, 1997); NT - near threatened, V - vulnerable species, $\mathrm{R}$ - rare species

\begin{tabular}{|c|c|c|c|c|c|}
\hline Species & $\begin{array}{c}\text { Legal } \\
\text { protection }\end{array}$ & PCL & R. K-P & $\begin{array}{c}\text { Oxbow lakes } \\
\text { (Number } \\
\text { of occurrences) }\end{array}$ & $\begin{array}{c}\text { Fishponds } \\
\text { (Number } \\
\text { of occurrences) }\end{array}$ \\
\hline Angelica archangelica subsp. litoralis & Partial & - & $\mathrm{V}$ & 2 & - \\
\hline Asperugo procumbens & - & NT & - & - & 2 \\
\hline Batrachium aquatile & - & - & $\mathrm{R}$ & - & 3 \\
\hline Hippuris vulgaris & - & - & $\mathrm{V}$ & - & 2 \\
\hline Lathyrus palustris & Partial & - & $\mathrm{V}$ & 5 & - \\
\hline Menyanthes trifoliata & Partial & - & - & 1 & - \\
\hline Senecio congestus & - & NT & - & - & 5 \\
\hline Sonchus palustris & - & - & $\mathrm{R}$ & - & 1 \\
\hline
\end{tabular}




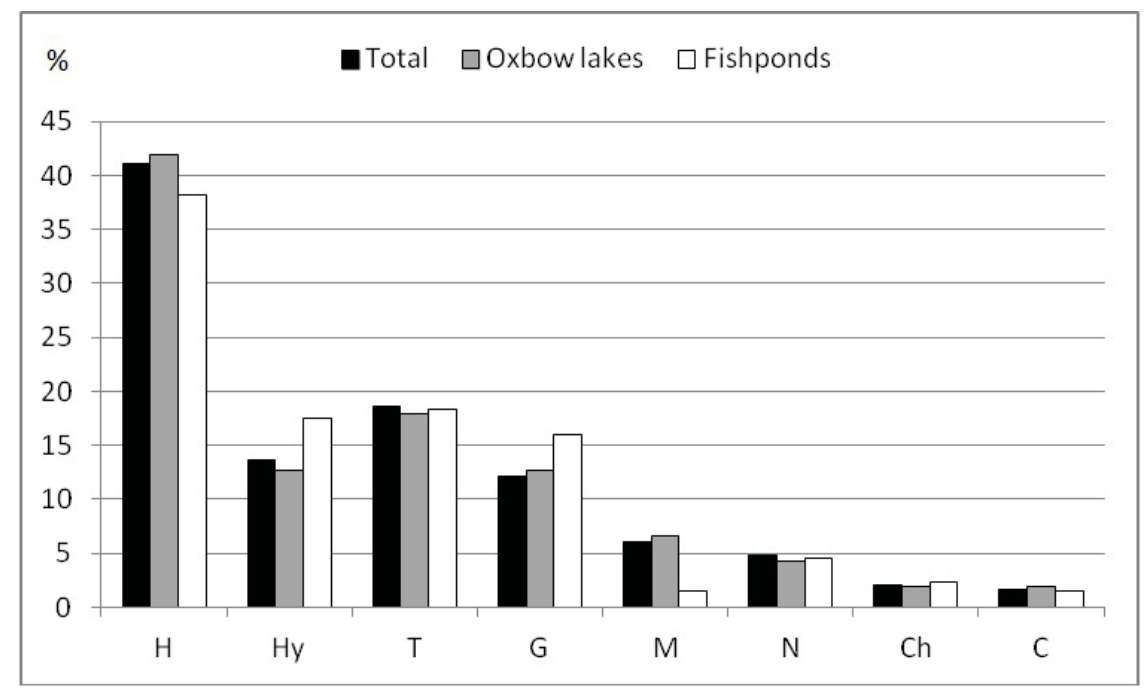

Figure 2. Comparison of the species life-form spectrum; H - hemicryptophytes, Hy - hydrophytes and helophytes, $\mathrm{T}$ - therophytes, $\mathrm{G}$ - geophytes, $\mathrm{M}$ - megaphanerophytes, $\mathrm{N}$ - nanophanerophytes, $\mathrm{Ch}$ - woody chamaephytes, $\mathrm{C}$ - non-woody chamaephytes

Table 3. Indices of anthropogenic changes in the flora of oxbow lakes and fishponds

\begin{tabular}{lccc}
\hline \multicolumn{1}{c}{ Index } & Total & Oxbow lakes & Fishponds \\
\hline Index of natural character $(N)$ & $45.16 \%$ & $45.28 \%$ & $40.46 \%$ \\
Index of specific synanthropization $\left(S_{w}\right)$ & $54.84 \%$ & $54.71 \%$ & $59.54 \%$ \\
Index of specific apophytization $(A p w)$ & $43.14 \%$ & $46.23 \%$ & $47.33 \%$ \\
Index of total anthropophytization $\left(A_{n}\right)$ & $11.69 \%$ & $8.49 \%$ & $12.21 \%$ \\
\hline
\end{tabular}

The more abundant flora of the oxbow lakes was represented by species belonging to 20 phytosociological classes, whilst the flora of the fishponds was represented by taxa from only 14 classes (Fig. 4). Both in the natural and artificial reservoirs, the most numerous were representatives of Molinio-Arrhenatheretea and Phragmitetea australis. The flora of the oxbow lakes contained a larger proportion of taxa from Molinio-Arrhenatheretea, Stellarietea mediae, Querco-Fagetea, Rhamno-Prunetea and Scheuchzerio-Caricetea fuscae. Edificators of the following classes were found exclusively in this group of water bodies (more specifically - in their surroundings): Koelerio-Corynephoretea, Trifolio-Geranietea sanguinei, Epilobietea angustifolii, Festuco-Brometea and Isoëto durieuiJuncetea bufonii. The flora of the fishponds was characterized by the dominance of taxa from Phragmitetea australis, Artemisietea vulgaris, Bidentetea tripartitae, Potametea, Lemnetea minoris, Salicetea purpureae, Alnetea glutinosae, Montio-Cardaminetea and Polygono-Poetea annuae.
The differences in the floras of these water bodies are also illustrated by the Principal Component Analysis - PCA (Fig. 5). The gradient represented by the first axis explains $19.6 \%$ and by the second axis $-14.6 \%$ of the total species variance. Relevés from the fishponds are clustered on the left side, while from the oxbow lakes - on the right side of the diagram. The diagram indicates that the species more associated with the oxbow lakes include, e.g.: Alnus glutinosa, Carex paniculata, Iris pseudacorus, Lemna gibba, Lysimachia vulgaris, Stratiotes aloides, Stachys palustris and Thelypteris palustris. In the artificial reservoirs, Anthriscus sylvestris, Batrachium aquatile, Epilobium hirsutum, Galium aparine, Typha angustifolia and Potamogeton lucens are more abundant. It can be assumed that the $\mathrm{x}$-axis explains the species diversity, while the $y$-axis represents the moisture conditions - dry water bodies are placed at the peripheral parts of the diagram, above the $\mathrm{x}$-axis. 


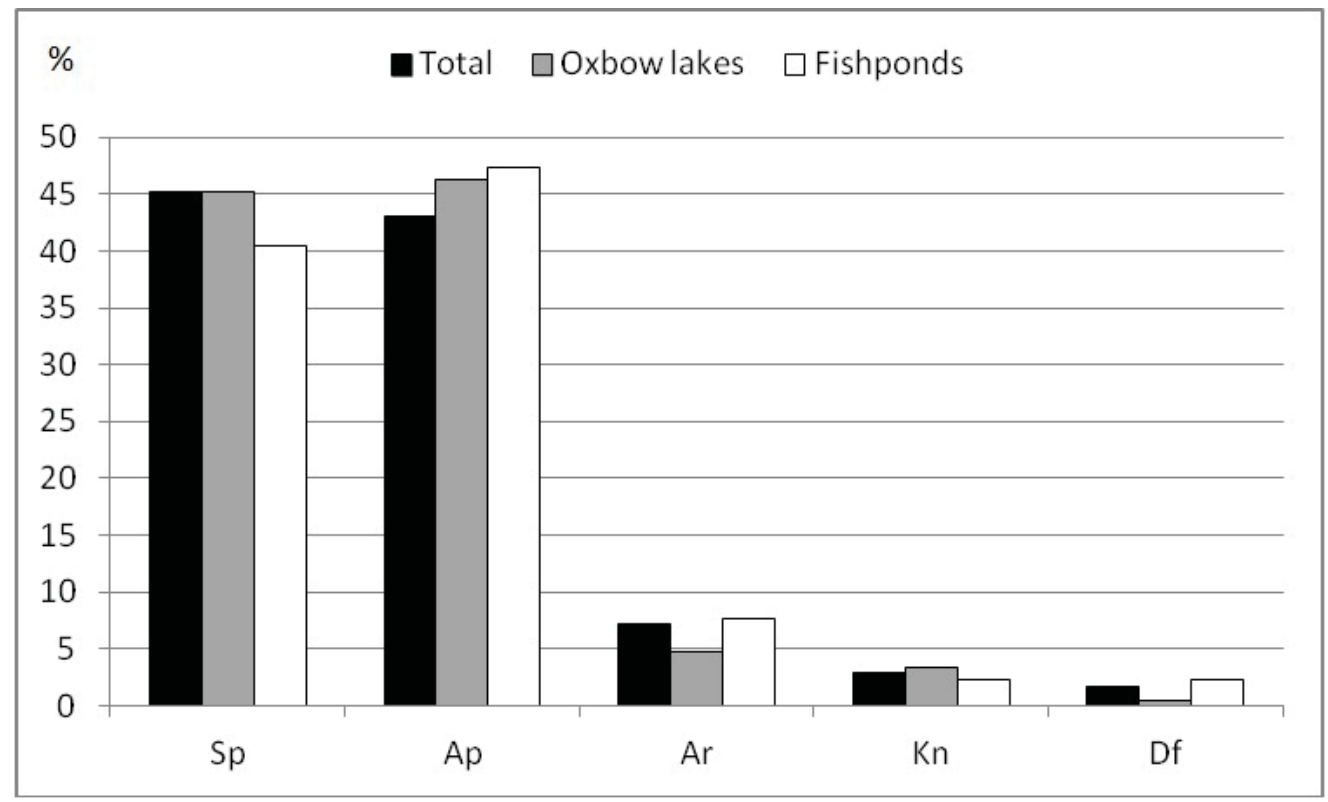

Figure 3. Comparison of geographical and historical groups' contribution; Sp - non-synanthropic spontaneophytes, Ap - apophytes, Ar - archaeophytes, Kn - kenophytes, Df - diaphytes

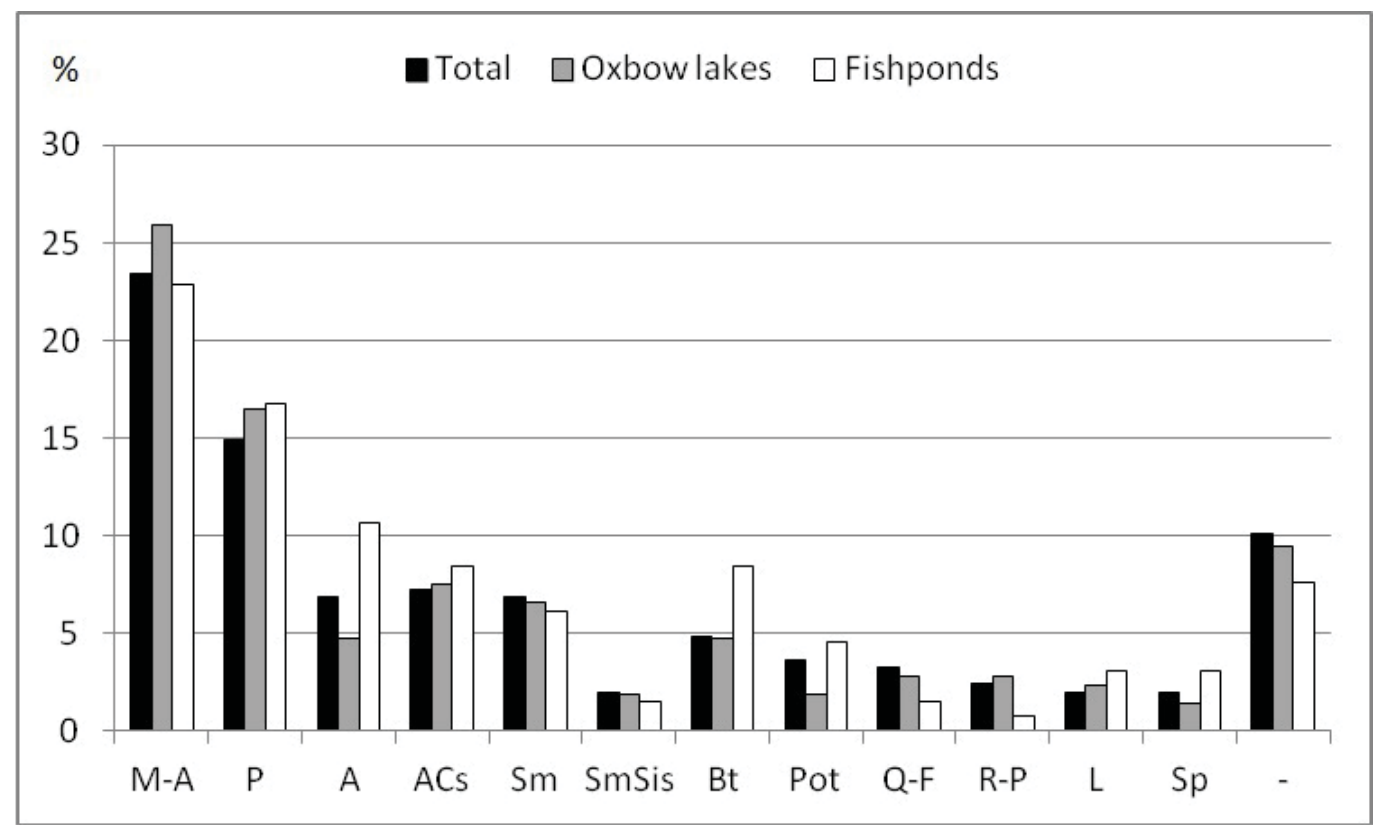

Figure 4. Contribution of phytosociological classes to the total number of species; M-A - Molinio-Arrhenatheretea, P - Phragmitetea australis, A - Artemisietea vulgaris (Onopordetalia acanthii), ACs - Artemisietea vulgaris (Convolvuletalia sepium), Sm - Stellarietea mediae (Papaveretalia rhoeadis, Aperetalia spicae venti), SmSis - Stellarietea mediae (Sisymbrietalia), Bt - Bidentetea tripartitae, Pot - Potametea, Q-F - Querco-Fagetea, R-P - Rhamno-Prunetea, L - Lemnetea minoris, $\mathrm{Sp}$ - Salicetea purpureae, K-C - Koelerio-Corynephoretea, T-G - Trifolio-Geranietea, Ag - Alnetea glutinosae, F-B - Festuco-Brometea, E-A - Epilobietea angustifolii, S-Cf Scheuchzerio-Caricetea fuscae, I-N - Isoëto durieui-Juncetea bufonii, C-U - Calluno-Ulicetea, M-C - Montio-Cardaminetea, P-P - Polygono-Poetea annuae, V-P - Vaccinio-Piceetea, - without phytosociological affinity 
The differences between the reservoirs were also confirmed by UPGMA analysis, where all reservoirs were divided into two main groups: one group with the oxbow lake without water, while the other group contained clearly differentiated oxbow lakes and fishponds (Fig. 6).

\section{Discussion}

Due to their natural origin, oxbow lakes are extremely valuable ecosystems, representing a protected natural habitat habitat code 3150-2 (Obwieszczenie Ministra Środowiska, 2014). Despite their anthropogenic genesis, fishponds are also characterized by the presence of communities indicative of the above type of habitat.

Both the fishponds and oxbow lakes in this study are floristically extremely abundant environments, playing an important role in the preservation of the local biodiversity. This is confirmed by the high values of the species diversity index. In comparison to 450 small water reservoirs (mainly kettle-holes) in the Krajna Lakeland, located in different types of landscapes (Waldon, 2011), where the average value of this index was 5.29, the oxbow lakes in this study have a higher diversity (5.76), while the fishponds - lower diversity (5.27). The evenness index, as a measure of how evenly the species are distributed, has high and similar values -0.98 in the oxbow lakes and fishponds and 0.97 in small water reservoirs in the Krajna Lakeland.

Up to 213 species of vascular plants were recorded in 10 oxbow lakes distributed along a $2.5 \mathrm{~km}$ section of the middle Noteć River valley, and 113 species in 10 ponds located in the valley of the Bydgoszcz Canal. For comparison, up to 171 taxa were found in protected "Sta-

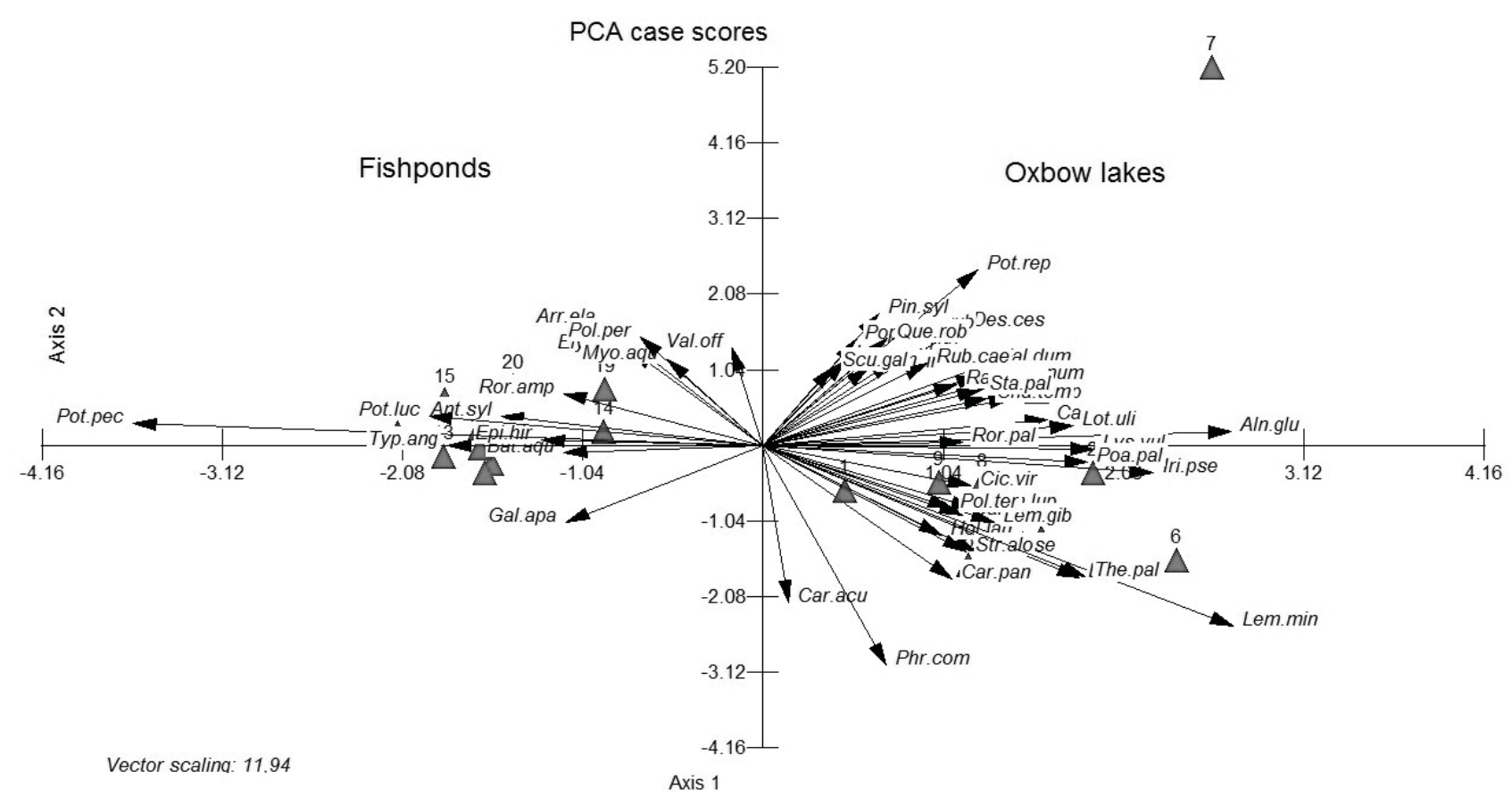

Figure 5. Principal Component Analysis (PCA) for the flora of oxbow lakes and fishponds (short vectors hidden); Aln.glu - Alnus glutinosa, Ant.sil - Anthriscus silvestris, Arr.ela - Arrhenatherum elatius, Bat.aqu. - Batrachium aquatile, Car.acu - Carex acutiformis, Car.pat - Carex paniculata, Cic.vir - Cicuta virosa, Des.ces - Deschampsia caespitosa, Epi.hir - Epilobium hirsutum, Fal.dum - Fallopia dumetorum, Gal.apa - Galium aparine, Iri.pse - Iris pseudacorus, Lem.gib - Lemna gibba, Lem.min - Lemna minor, Lot.uli - Lotus uliginosus, Lys.vul - Lysimachia vulgaris, Myo.aqu - Myosoton aquaticum, Phr.aus - Phragmites australis, Pin.syl - Pinus sylvestris, Poa.pal - Poa palustris, Pol.per - Polygonum persicaria, Pol. ter-Polygonum amphibium f. terrestre, Potamogeton lucens, Pot.rep - Potentilla reptans, Que.rob - Quercus robur, Ror. amp - Rorippa amphibia, Rub.cae - Rubus caesius, Scu.gal - Scutellaria galericulata, Sta.pal - Stachys palustris, Str.alo Stratiotes aloides, The.pal - Thelypteris palustris, Typ.ang - Typha angustifolia, Val.off - Valeriana officinalis 
rorzecze Łacha Farna" in the Oder River valley (Proćków \& Proćków, 2008). Knežević et al. (2009) reported 174 plant species in one of the oxbow lakes of the Tisa River in Serbia, and Krawczyk (2010) found only 83 aquatic and shrub species in 28 oxbow lakes of the San River. Kucharski et al. (2013) recorded 152 vascular plant species in 20 oxbow lakes located within a several-kilometre section of the Warta River valley. The number of reported taxa can be affected by the size of the studied water bodies, their immediate surroundings, human impact, as well as the methodological approach - some authors included only aquatic vegetation in the analysis, while most analyses (including the present one) included also the shores of the reservoirs.

The floristic abundance is also affected by the waterlevel oscillations, e.g. the largest number of species was recorded in the dry oxbow lake (107).

There are fewer papers published on the flora of fishponds. A total of 172 taxa of vascular plants were recorded in four fishponds (the "Polder" reserve in Lower Silesia) (Klupak \& Szczęśniak, 2010). Krawczyk (2005) reported 320 species of vascular plants in 11 fishponds in the Sandomierz Basin, while Nowicka-Falkowska and Falkowski (2001) found 629 species of vascular plants in 41 complexes of fishponds in the South Podlasie Plain.

The flora of the studied oxbow lakes is much more abundant than that of the fishponds, which is most likely associated with greater diversity of these habitats and their surroundings, i.e. not only meadows, as in the case of ponds, but also forest communities. Half of the oxbow lakes were surrounded by Carici elongatae-Alnetum or Fraxino-Alnetum forests.
The more natural character of the oxbow lakes is reflected in the presence of forests at their shores, more abundant occurrence of phanerophytes, and thus a much higher proportion of species from the Querco-Fagetea and Rhamno-Prunetea classes. Frequent mowing of the fishpond shores results in more frequent and more abundant occurrence of herbaceous species from the Artemisietea vulgaris class (by nearly $8 \%$ ).

Periodic draining of fishponds as well as artificial exposure of their shores result in almost twice as many species with short life cycles from the Bidentetea tripartitae class $(8.4 \%)$. It is worth noting that aquatic taxa from the Lemnetea minoris and Potametea classes were much more abundant in the pelagic zone of the artificial water bodies - due to less shade, while shrub taxa from Salicetea purpureae were observed more frequently on their shores due to the lack of competition from trees. In addition, the steep shores of fishponds result in poorly formed ecotone zones and, therefore, rushes usually occur in the form of narrow strips (Pełechaty, 1998). Similarly, Negishi et al. (2014) draw attention to a smaller contribution of macrophytes on the shores of fishponds in relation to reservoirs with naturally shaped shores. The reservoirs compared in this study were characterized by a similar contribution of Phragmitetea australis and Scheuchzerio-Caricetea fuscae species, which is related to the fact that rushes had also developed on the bottom of three of the studied fishponds as a result of the lowered water level.

Due to the presence of causeways with paths and roads between the ponds and various management works associated with their maintenance and fish breeding, the total

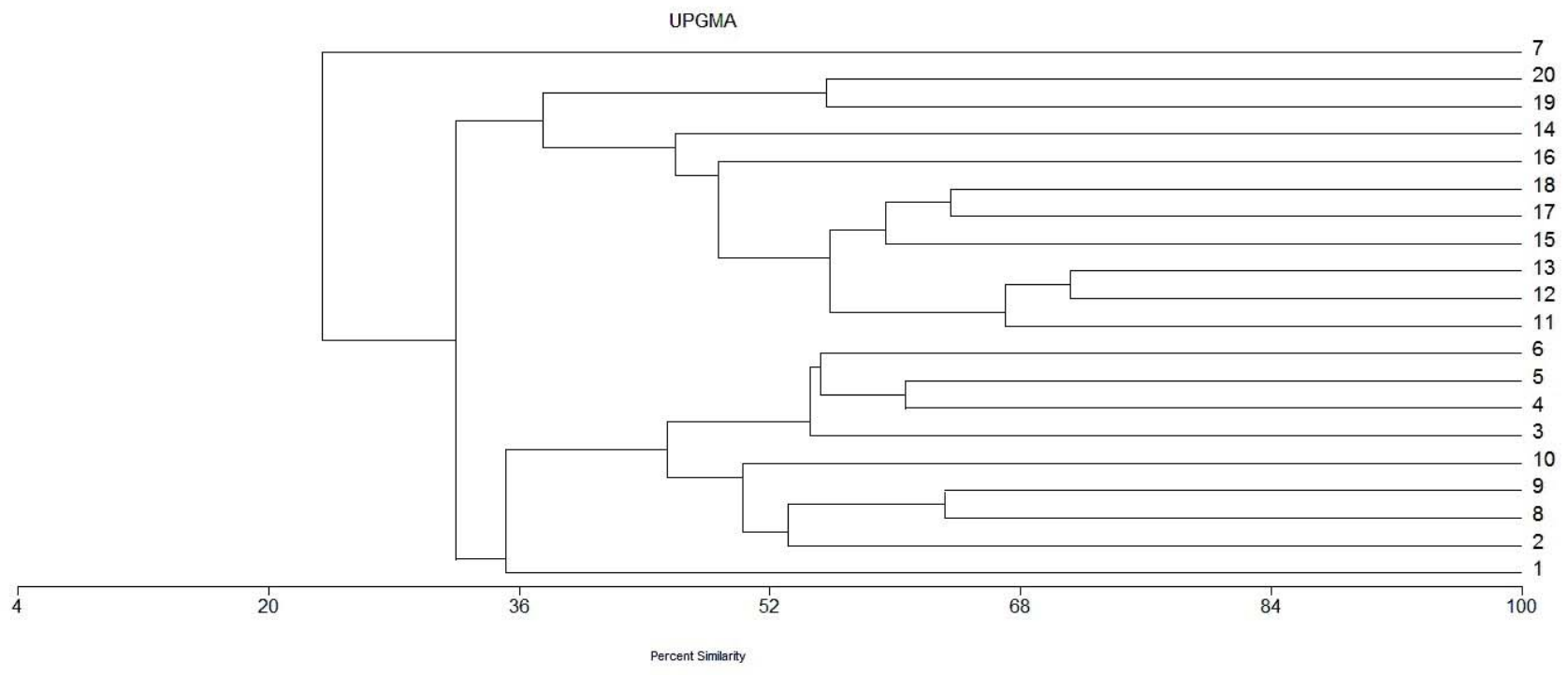

Figure 6. Unweighted Pair Group Method with Arithmetic Mean (UPGMA) for the flora of oxbow lakes (1-10) and fishponds (11-20) 
contribution of ruderal species (mainly from Onopordetalia acanthii, Sisymbrietalia and Polygono-Poetea) was much higher in the case of artificial reservoirs (almost $13 \%$ ) compared to the natural ones $(7.1 \%)$.

The greater naturalness of the oxbow lakes is reflected not only in the higher value of the flora naturalness index and the higher relative abundance of native species, but also in the more frequent presence of protected taxa (Table 2, Fig. 2). It is worth noting that the Noteć River valley oxbow lakes had a high value of the flora naturalness index $-45.3 \%$, which is higher than that reported for the Warta River oxbow lakes $-32.4 \%$ (Kucharski et al., 2013). Despite twice as many oxbow lakes being studied in the Warta River valley, the same number of protected species were found as in the case of the Noteć River oxbow lakes. This may be due to the fact that only 2 out of the 20 oxbow lakes studied by those authors were adjacent to forest communities, while the others were located among meadows and fields.

Sikorska et al. (2011) draw attention to the impact of the immediate surroundings on the degree of oxbow lakes' flora naturalness. For example, the proximity of agricultural areas (meadows, pastures, wastelands) contributes to a reduced proportion of native species in oxbow lakes, while the vicinity of forests has a positive impact on their presence.

The slightly larger contribution of kenophytes in the flora of the oxbow lakes compared to the fishponds may result from the greater vulnerability of riverine ecosystems to the penetration of geographically alien taxa (Pyšek \& Prach, 1996; Hood \& Naiman, 2000; Tokarska-Guzik, 2005). Examples of such plant species in the oxbow lakes of the Noteć River are: Acorus calamus, Bidens frondosa, and Elodea canadensis.

The differences between the analysed floras were confirmed by statistical analysis (PCA, UPGMA). Nevertheless, the structure of plant communities in small water bodies and, consequently, the distribution of relevés representing this vegetation in the ordination diagrams and dendrograms of hierarchical classification are affected by a number of factors, including the nature of the immediate surroundings, the trophic status of a water body and the $\mathrm{pH}$ value (Waldon, 2011, 2012).

Many authors draw attention to the rapid renaturalization of artificial water reservoirs, i.e. fishponds, and the possibility of their colonization by native flora and vegetation typical for natural water bodies (Kucharski \& Samosiej, 1993; Ratyńska, 2003; Klupak \& Szczęśniak, 2010; Waldon 2011, 2012). It is worth noting that the studied fishponds in the Bydgoszcz Canal valley are characterized by higher values of flora naturalness $(40.7 \%)$ than oxbow lakes in the Warta River valley - 33.7\% (Kucharski et al., 2013). This is likely due to the fact that the fishponds in Ślesin were established a few decades ago and are located in a naturally formed river valley, which is used as a grassland, creating a significant barrier for the penetration of non-indigenous species.

Falkowski and Nowicka-Falkowska $(2001,2004)$ emphasize that the importance of fishpond complexes as a refuge for the vascular flora dates back to the very beginning of these objects, in most cases the eighteenth and nineteenth centuries. It is long enough for these artificial reservoirs to become an integral part of the landscape. The extensive fishery management with a tendency to reduce production has a particular impact on the diversity of habitats, which favours the occurrence of species representing different ecological requirements. The size and shape of a reservoir (Soga et al., 2014), as well as the connection with the landscape type, are also important to the biological diversity. All this means that complexes of fishponds are characterized by a relatively high degree of naturalness of the flora and plant communities, which has been confirmed by the results obtained by other authors (NowickaFalkowska \& Falkowski, 2006). Falkowski et al. (2009) found up to 79 endangered species, including 7 orchid species (Nowicka-Falkowska \& Falkowski, 2006) in 44 complexes of fishponds in central-eastern Poland.

The role of artificial reservoirs as temporary habitats and places for the survival of relict species has been increasingly emphasized (Bolpagni et al., 2013). For instance, Coleanthus subtilis - a grass species listed in Annex II of the Habitats Directive occurs in Poland only around fishponds: in Borowa Olesińska near Wrocław (Fabiszewski \& Cebrat, 2003) and in Stawy Milickie in the Barycz River valley (Czarna et al., 2013).

In the recent decades, due to the global decline in the wetlands and, consequently, biodiversity loss, projects aimed at restoring the degraded wetland habitats and water reservoirs are increasingly being implemented (Oertli et al., 2014; Sebastian-Gonzalez \& Green, 2014; Espanol et al., 2015). This is important as these actions are beneficial for the development and survival of as many organisms as possible (Lemmens et al., 2013).

\section{Conclusions}

It was confirmed that the flora of the Notec River valley oxbow lakes and fishponds located in valley of the Bydgoszcz Canal differ from each other. A good indicator of differentiation is the spectrum of species proportions in each class, which is determined by the origin of reservoirs, their surroundings, and the degree of anthropopressure.

Because of their natural origin and location within natural and semi-natural ecosystems, the oxbow lakes were characterized by more abundant and more natural flora than the fishponds. The assumption that old riverbeds would have a greater significance for the preserva- 
tion of protected and threatened plant species has not been confirmed. It turned out that 5 threatened species occur in the ponds, while only 3 protected species occur in the old riverbeds.

Both types of reservoirs are extremely valuable refuges for native flora, which is evidenced by the presence of protected and endangered species, a large contribution of nonsynanthropic spontaneophytes, as well as high and similar values of species diversity indices.

The fishponds, despite their anthropogenic origins and regular functioning associated with fish farming, provided a substitute habitat for many plant species, and they were characterized by a high degree of flora naturalness relative to the surrounding agricultural ecosystems.

The oxbow lakes were characterized by the presence of forest habitats in their immediate surroundings, and thus the more abundant occurrence of megaphanerophytes and much larger contribution of non-synanthropic spontaneophytes and apophytes from Molinio-Arrhenatheretea, Querco-Fagetea, Rhamno-Prunetea and ScheuchzerioCaricetea fuscae.

Periodic drainage of fishponds is conducive to the encroachment of terrestrial therophytes from Bidentetea tripartitae on their shores and it has a positive effect on the relative abundance of rush species.

Management practices associated with the maintenance of fishponds and the presence of a network of dykes and paths resulted in the more abundant occurrence of ruderal species within and around these artificial water bodies, while due to less shade in relation to the oxbow lakes, aquatic taxa from the Lemnetea minoris and Potametea classes were more abundant.

Although oxbow lakes are more valuable habitats in terms of nature, and hence they are partly protected in Europe from destruction, complexes of fishponds also require certain management practices aimed at their preservation, while taking into account the interests of managers/breeders.

\section{References}

Balázs A. \& Erdős L., 2011, Botanical survey of Southern Transdanubian oxbow lakes and the changes of the last 10 years. Natura Somogyiensis 19: 41-50.

Bolpagni S., Bartoli M. \& Viaroli P., 2013, Species and functional plant diversity in a heavily impacted riverscape: Implications for threatened hydro-hygrophilous flora conservation. Limnologica 43: 230-238.

Braun-Blanquet J., 1964, Pflanzensoziologie. Grundzüge der Vegetationskunde. Springer - Verlag, Wien - New York.

Broyer J. \& Curtet L., 2012, Biodiversity and fish farming intensification in French fishpond systems. Hydrobiologia 694(1): 205-218.
Czarna A., Maćkowiak Ł. \& Woźniak A., 2013, New localities of Coleanthus subtilis (Tratt.) Seid. (Poaceae) in the „Milicz Ponds” Ornithological Reserve in Wielkopolska. Botanika Steciana 17: 39-42.

Dawidek J. \& Ferencz B., 2005, Hydrochemical classification of the river lakes situated near the Bug River. Limnological Review 5: 53-59.

Espanol C., Gallardo B., Comin F.A. \& Pino M.R., 2015, Constructed wetlands increase the taxonomic and functional diversity of a degraded floodplain. Aquatic Sciences 77(1): 27-44.

Fabiszewski J. \& Cebrat J., 2003, Coleanthus subtilis (Tratt.) Seid. - a new species to Polish vascular flora. Acta Societatis Botanicorum Poloniae 72(2): 135-138.

Falkowski M. \& Nowicka-Falkowska K., 2001, Fishponds - Refuges of flora in agricultural landscape of the Południowopodlaska Lowland (Poland). Ekológia (Bratislava) 20, Supplement 3: 242-245.

Falkowski M. \& Nowicka-Falkowska K., 2004, Dependence of biodiversity of fishponds vegetation upon the intensity of fish farming. Teka Commissions of Protection and Formation of Natural Environment 1: 51-56.

Falkowski M., Nowicka-Falkowska K. \& Krechowski J., 2009, Endangered species of vascular flora in fishpond complexes of the central-eastern Poland. Electronic Journal of Polish Agricultural Universities. Biology 12(4). http://www.ejpau.media.pl/volume12/issue4/ art-29.html

Gąbka M. \& Dolata P.T., 2010, Rzadkie i zagrożone zbiorowiska hydrofitów stawów rybnych południowej Wielkopolski. Badania Fizjograficzne RI, B59: 75-96.

Hejný S., 1990, Dynamic changes in the macrophyte vegetation of South Bohemian fishponds after 35 years. Folia Geobotanica et Phytotaxonomica 25: 245-255.

Hood W.G. \& Naiman R.J., 2000, Vulnerability of riparian zones to invasion by exotic vascular plants. Plant Ecology 148: 105-114.

Jackowiak B., 1990, Antropogeniczne przemiany flory roślin naczyniowych Poznania [Anthropogenic changes of the flora of vascular plants of Poznań], Wyd. UAM, Poznań, B42: 1-232.

Kaźmierczakowa R., Bloch-Orłowska J., Celka Z., Cwener A., Dajdok Z., Michalska-Hejduk D., Pawlikowski P., Szczęśniak E. \& Ziarnek K., 2016, Polska czerwona lista paprotników i roślin kwiatowych. [Polish red list of Pteridophytes and flowering plants], Instytut Ochrony Przyrody PAN Kraków.

Klama H., Żarnowiec J. \& Chmura D., 2012, Szata roślinna projektowanego zespołu przyrodniczo-krajobrazowego Stare Wiślisko w Kotlinie Oświęcimskiej [Vegetation of projected landscape-nature protected area stare Wiślisko in Oświęcim basin - southern Poland]. Wyd. AT-H, Bielsko-Biała. 
Klupak M., Szczęśniak E., 2010, Flora naczyniowa antropogenicznych stawów w rezerwacie Polder (Dolny Śląsk) [The vascular flora of anthropogenic ponds in the nature reserve "Polder" (Lower Silesia)]. Acta Botanica Silesiaca 5: 43-64.

Knežević A., Boža P., Stankov M., Nikolić L.J., Stojanović S., Džigurski D., Ljevnaić B. \& Polić D., 2009. Plant cover of the saline grassland in the riparian zone of the Okanj oxbow lake (the Vojvodina Province, Serbia). Journal of Engineering Annals Hunedoara 7(4): 189-194.

Kondracki J., 2000, Geografia fizyczna Polski [Physical Geography of Poland]. Państwowe Wydawnictwo Naukowe, Warszawa.

Kovach W.L., 2002, MVSP - Multivariate Statistical Package. Version 3.1. Kovach Computing Services, Pentraeth, UK.

Krawczyk R., 2005, Szata roślinna kompleksu stawów rybnych w Lipie (Kotlina Sandomierska) jako lokalne centrum bioróżnorodności [The plant cover of fishpond in Lipa (Sandomierz Basin) as a local center of biodiversity]. Chrońmy Przyrodę Ojczystą 61(4): 34-45.

Krawczyk R., 2010, Species richness and vegetation structure in different morphogenetic types of river lakes in the San River valley. Annales University Mariae Curie Sklodowska C.65(1): 29-45.

Kubù F., Kvìt J. \& Hejný S., 1994, Fishpond management (Czechoslovakia), [in:] B.C. Patten (ed.), Wetlands and Shallow Continental Water Bodies, 2: 391-404. SPB Academic Publishing, The Hague.

Kucharski L., Barcka A. \& Chmielecki B., 2013, Flora starorzeczy w Dolinie Warty - stan, zagrożenia oraz możliwości ochrony [The oxbow lakes flora of valley Warta - condition, threats and possibility of protect]. Biuletyn Uniejowski 2: 23-38.

Kucharski L. \& Samosiej L., 1993, Wyznaczanie optymalnej sieci zagłębień śródpolnych w celu ochrony zasobów gatunków dziko rosnących w krajobrazie rolniczym [Determining the optimal net of mid-field depression for preserving wildly growing species in agricultural landscape]. Acta Universitatis Lodziensis, Folia Botanica 10: 109-121.

Lemmens P., Mergeay J., De Bie T., Van Wichelen J., De Meester L. \& Declerck S.A.J., 2013, How to maximally support local and regional biodiversity in applied conservation? Insights from pond management. PLoS One 8(8): e72538.

Matìna J. \& Berka R., 1987, Fresh-water fish-pond management in the world, [in:] R.G. Michael (ed.), Management Aquatic Ecosystems. Ecosystems of the World, 29: 3-27. Elsevier, Amsterdam.

Matuszkiewicz J.M., 2008, Potential natural vegetation of Poland. IGiPZ PAN, Warszawa.
Mirek Z., Piękoś-Mirkowa H., Zając A. \& Zając M., 2002, Flowering plants and pteridophytes of Poland. A checklist. Biodiversity of Poland, Vol. 1. W. Szafer Institute of Botany, Polish Academy of Sciences, Kraków.

Negishi J.N., Soga M., Ishiyama N., Suzuki N., Yuta T., Sueyoshi M., Yamazaki C., Koizumi I., Mizugaki S., Hayashida K., Nunokawa M. \& Yoshimura N., 2014, Geomorphic legacy controls macrophyte distribution within and across disconnected floodplainlakes. Freshwater Biology 59(5): 942-954.

Nowicka-Falkowska K. \& Falkowski M., 2006, Fispond areas - sites of abundant occurence of Orchidaceae, [in:] T.S. Olszewski, R. Afranowicz, K. Baciąg (eds), Contemporary trends of botanical research - on Professor Hanna Piotrowska 89th anniversary. Acta Botanica Cassubica 6: 85-92.

Obwieszczenie Ministra Środowiska z dn. 30 października 2014 w sprawie ogłoszenia jednolitego tekstu rozporządzenia Ministra Środowiska w sprawie siedlisk przyrodniczych oraz gatunków będących przedmiotem zainteresowania Wspólnoty, a także kryteriów wyboru obszarów kwalifikujących się do uznania lub wyznaczenia jako obszary Natura 2000. Dz. U. 2014, poz. 1713, Warszawa [Notice of the Ministry of Environment of 30 October 2014 on the announcement of the uniform text of the Regulation of the Minister of the Environment on natural habitats and species of Community interest, as well as criteria for selecting areas that are eligible for recognition or designation as Natura 2000 sites. Journal of Laws 2014, item 1713, Warsaw].

Oertli B., Ilg C., Angelibert S., Bolliger J., Crovadore J., Demierre E., Julliand C., Finger-Stich A., Forre C., Frossard P.A., Lefort F., Mayencourt M., Piantini U. \& Schmid S., 2014, Freshwater biodiversity under warming pressure in the Alps: a methodological framework for prioritization of restoration areas for small waterbodies. Eco Mont-Journal on Protected Mountain Areas Research 6(1): 23-34.

Pełechaty M., 1998, The role of ecotones in aqueous ecosystems, [in:] L. Burchardt (ed.), The Theoretical and the Practical Aspects in the Ecological Investigations. Idee Ekologiczne 10/6: 151-155.

Pieczyńska E., 1988, Rola makrofitów w kształtowaniu trofii jezior [Effect of macrophytes on lake trophy]. Wiadomości Ekologiczne 34(4): 375-404.

Podbielkowski Z., 1968, Roślinność stawów rybnych województwa warszawskiego [The vegetation of fishponds in Warsaw voivodeship]. Monographiae Botanicae 27: 3-123.

Proćków J. \& Proćków M., 2008, Szata roślinna użytku ekologicznego Starorzecze Łacha Farna (NW Wrocław, woj. dolnośląskie) [Plant cover of the "Lacha Farna Old River-bed" area of ecological use - NW Wrocław, 
Dolnośląskie voivodeship]. Acta Botanica Silesiaca 3: 83-105.

Pyšek P. \& Prach K., 1996, Plant invasions and the role of riparian habitats: a comparison of four species alien to central Europe. Journal of Biogeography 20: 413-420.

Ratyńska H., 2003, Szata roślinna jako wyraz antropogenicznych przekształceń krajobrazu na przykładzie zlewni rzeki Głównej (środkowa Wielkopolska) [Plant cover as a result of anthropogenic changes in landscape exemplified by the River Głowna catchment area, the middle Wielkopolska Province]. Wydawnictwo Akademii Bydgoskiej, Bydgoszcz.

Ratyńska H. \& Szwed W., 1999, Struktura roślinności starorzeczy jako wyraz dynamiki warunków siedliskowych [Vegetation structure of oxbow lakes as reflection of habitat Dynamics]. Przegląd Przyrodniczy 10(3-4): 33-48.

Ratyńska H., Wojterska M., Brzeg A. \& Kołacz M., 2010, Multimedialna encyklopedia zbiorowisk roślinnych Polski [Multimedia encyclopedia of plant communities in Poland], Ver. 1.1. NFOŚGW, Uniwersytet Kazimierza Wielkiego, IETI, Bydgoszcz.

Rozporządzenie Ministra Środowiska z dnia 16 października 2014 r. w sprawie ochrony gatunkowej roślin. Dz. U. 2014, poz. 1409, Warszawa [Regulation of the Minister of the Environment of 16 October 2014 on the protection of plant species. Journal of Laws 2014, item 1409, Warsaw].

Rutkowski L., 1997, Vascular plants - Tracheophyta, [in:] J. Buszko, K. Kasprzyk, T. Pawlikowski, A. Przystalski, L. Rutkowski (eds), Red list of endangered plants and animals of Kuyavian-Pomeranian region. Acta Univ. Nicolai Copernici. Biologia 53, Supplement 98: 9-20.

Rutkowski L., 2011, Klucz do oznaczania roślin naczyniowych Polski niżowej [Classification Key to Vascular Plants of Lowland Poland]. Państwowe Wydawnictwo Naukowe, Warszawa.

Sebastian-Gonzalez E. \& Green A.J., 2014, Habitat Use by Waterbirds in Relation to Pond Size, Water Depth, and Isolation: Lessons from a Restoration in Southern Spain. Restoration Ecology 22(3): 311-318.

Shannon C.E. \& Weaver W., 1949, The mathematical theory of communication. University of Ilinois Press, Urbana.

Sikorska D., Sikorski P. \& Chwedoruk J., 2011, Degradation of Oxbow Lakes Vegetation under Urbanization Pressure. Contemporary Problems of Management and Environmental Protection. Issues of Landscape Conservation and Water Management in Rural Areas 7: 123-136.
Soga M., Ishiyama N., Sueyoshi M., Yamaura Y., Hayashida K., Koizumi I. \& Negishi J.N., 2014, Interaction between patch area and shape: lakes with different formation processes have contrasting area and shape effects on macrophyte diversity. Landscape Ecology Engineering 10(1): 55-64.

Solon J., 1983, The local complex of phytocenoses and the vegetation landscape - fundamental units of the spatial organization of the vegetation above the phytocenose level. Acta Botanica Hungarica 29 (1-2): 377-384.

Szumiec M.A., 1995, The role of carp pond ecosystem management in wetland conservation. Acta Hydrobiologica 37, Supplement 1: 13-20.

Tokarska-Guzik B., 2005, The Estabilishment and Spread of Alien Plant Species (Kenophytes) in the flora of Poland. Prace Nauk Uniwersytetu Śląskiego, Katowice.

Tomaszewicz H., 1969, Roślinność wodna i szuwarowa starorzeczy Bugu na obszarze województwa warszawskiego [The water and swamp vegetation of closed meander of River Bug in Warsaw region]. Acta Societatis Botanicorum Poloniae 37(2): 217-245.

Waldon B., 2011, Drobne zbiorniki wodne Pojezierza Krajeńskiego jako ostoje różnorodności szaty roślinnej [Small water bodies in the Krajeńskie Lakeland as diversity of vegetation refuges]. Wydawnictwo Uniwersytetu Kazimierza Wielkiego, Bydgoszcz.

Waldon B., 2012, The conservation of small water reservoirs in the Krajeńskie Lakeland (North-West Poland). Limnologica 42: 320-327.

Wezel A., Oertli B., Rosset V., Arthaud F., Leroy B., Smith R., Angélibert S., Bornette G., Vallod D. \& Robin J., 2013, Biodiversity patterns of nutrient-rich fish ponds and implications for conservation. Limnology 15(3): 213-223.

Wojtaszek M., 1989, Roślinność starorzeczy prawobrzeżnej doliny Warty w rejonie Rogalina [Vegetation of old river-beds on the right bank of Warta in the region of Rogalin]. Badania Fizjograficzne nad Polską Zachodnią B39: 105-117.

Załącznik 1 do Dyrektywy 92/43/EEC z dnia 21 maja 1992 r. w sprawie ochrony siedlisk naturalnych oraz dzikiej fauny i flory: typy siedlisk przyrodniczych ważnych dla wspólnoty, których ochrona wymaga wyznaczenia specjalnych obszarów ochrony [Annex 1 to Directive 92/43/EEC of 21 May 1992 on the conservation of natural habitats and of wild fauna and flora: types of habitats and species of Community interest whose protection requires the designation of special areas of conservation]. Official Journal L 206, 22/07/1992 P. $0007-0050$. 